\title{
Evaluation for the flowers of compositae plants as whitening cosmetics functionality
}

\author{
Yeong-Geun Lee ${ }^{1} \cdot$ Junghoon Lee $^{1} \cdot$ Na-Yeong Lee ${ }^{1} \cdot$ Nam-Kyun Kim $^{1} \cdot$ \\ Da-Won Jung ${ }^{1}$ - Weiyi Wang ${ }^{1}$ - Yoosung Kim ${ }^{1}$ - Hyoung-Geun Kim ${ }^{1}$. \\ Thi Nhan Nguyen ${ }^{1} \cdot$ Haseung Park ${ }^{2} \cdot$ Nam-In Baek ${ }^{1}$
}

\section{국화과 꽃의 미백 화장품 기능성 검색}

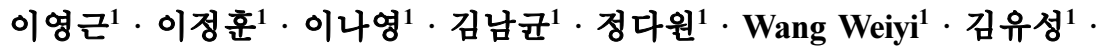 \\ 김형근 ${ }^{1} \cdot$ Nguyen Thi Nhan ${ }^{1}$. 박하숭 ${ }^{2} \cdot$ 백남인 $^{1}$
}

Received: 4 October 2016 / Accepted: 17 October 2016 / Published Online: 31 March 2017

(C) The Korean Society for Applied Biological Chemistry 2017

\begin{abstract}
Compositae family were collected and extracted in aqueous methanol $(\mathrm{MeOH})$. The concentrated extract was partitioned into $n$-hexane, ethyl acetate (EtOAc), $n$-BuOH, and water fractions. The extract and fractions were evaluated for total phenolics, total flavonoids, 1,1-diphenyl-2-picrylhydrazyl (DPPH) radical scavenging activity, and tyrosinase inhibition activity. $n$-Hexane and EtOAc fractions of Aster yomena, $n$ hexane fraction of Cosmos bipinnatus White, $n$-hexane and EtOAc fractions of $C$. bipinnatus Pink showed high total phenolics. And EtOAc fractions of A. yomena, C. bipinnatus White, $C$. bipinnatus Red, $C$. morifolium Froggy, and $C$. morifolium Himaya exhibited high total flavonoids. EtOAc fractions of A. yomena, C. bipinnatus White, C. bipinnatus Pink, C. morifolium Yellowmable, and $\mathrm{MeOH}$ extract of $C$. morifolium Rosa significantly scavenged DPPH radical. EtOAc fractions of C. chinensis, C. bipinnatus White, C. bipinnatus Red, $C$. morifolium Himaya, and C. morifolium Hongsim highly inhibited
\end{abstract}

Nam-In Baek $(\bowtie)$

E-mail: nibaek@khu.ac.kr

${ }^{1}$ Graduate School of Biotechnology and Department of Oriental Medicine Biotechnology, Kyung Hee University, Yongin 17104, Republic of Korea

${ }^{2}$ Yesan Chrysanthemum Experiment station, Chungcheongnam-do Agricultural Research \& Extension Services, Yesan 32418, Republic of Korea

This is an Open Access article distributed under the terms of the Creative Commons Attribution Non-Commercial License (http://creativecommons. org/licenses/by-nc/3.0/) which permits unrestricted non-commercial use, distribution, and reproduction in any medium, provided the original work is properly cited. the tyrosinase activity. A. yomena, C. bipinnatus White, $C$. bipinnatus Pink, $C$. bipinnatus Red and $C$. morifolium Himaya are evaluated as good source for whitening cosmetics materials.

Keywords Antioxidant $\cdot$ Compositae $\cdot$ 1,1-diphenyl-2picrylhydrazyl $\cdot$ Flower · Total flavonoids · Total phenolics . Tyrosinase $\cdot$ Whitening

\section{서 론}

꽃은 속씨식물의 생식기관이다. 꽃은 암술, 수술, 꽃잎, 꽃받침 으로 이루어져 있다. 꽃은 꽃자루의 끝에서 피고 모양과 크기, 빛깔이 매우 다양하다. 꽃은 번식을 위하여 생식기관으로써 화 분과 밑씨에 있는 난세포라는 생식세포를 만들어 내고, 꽃가루 매개자인 곤충이나 동물을 유인해 수정하게 하여 생식을 돕는 역할을 하게 한다(Harper 1977). 꽃은 이를 위해 향기를 내는 정유성분이나 색을 나타내는 안토시아닌과 같은 색소물질을 함 유하고 있다. 그 외에도 식물체가 외부의 자극에 저항하는 기 능과 꽃의 개화, 열매와 종자의 성숙과 관련된 조절기능 등 특 정 기능을 수행하기 위하여 다양한 대사산물을 생성한다(Hopkins 2006). 인간은 예로부터 꽃을 관상용, 향료나 염료로 사용하여 왔으며 또한 심리적인 치료요법 등에도 활용해 왔다(Kim 2005). 최근에 과학적 기술의 발전에 따라 꽃으로부터 다양한 활성물 질의 추출이 가능해졌으며 이에 따라 화장품 개발에 꽃의 활용 이 가능해졌다. 특히 꽃의 이차대사산물은 다양한 생리적 활성 과 약리적 효능을 가지고 있어 현재 이를 이용하여 새로운 의 
약물질 및 기능성 화장품 등의 개발이 다양하게 연구되고 있다. 21 세기는 경제적 여유와 문화적 수준이 향상됨에 따라 개인의 건강과 더불어 미에 대한 관심이 어느 때보다 높은 시대가 되 었다. 사람들의 삶이 이전보다 더욱 다양화 및 개성화 되면서 개인의 미에 대한 욕구도 함께 높아졌으며 이것은 화장품에 대 한 소비증가를 가져왔다. 2013년 우리나라 화장품 산업의 시장 규모는 약 7조원으로 최근 5년간 연평균성장률(2009-2013)이 $8.3 \%$ 로 빠르게 증가하고 있는 추세이다. 그 중 기능성 화장품 생산액은 약 2 조원으로 전년대비 $31.0 \%$ 급격하게 증가하였다 (Lee 2014), 기능성 화장품은 미백, 주름개선, 자외선차단으로 그 기능을 규정하고 있다(Im 2004). 기능성 화장품 중 미백기 능성화장품의 원료개발에 있어, 천연물에 대한 연구는 전통의학 에 기반을 둔 원료개발이라는 점과 우리나라 소비자들의 식물 성화장품에 대한 선호도가 높다는 점이 맞물려 국내 화장품 개 발의 주력분야가 되고 있다. 또한 기능성을 부여 하기 위해 첨 가된 각종 합성물질들이 여러 가지 부작용을 초래함에 따라 자 연 친화적인 소재의 탐색 및 개발은 중요한 논제로 떠오르게 되었다. 미백기능성화장품은 동식물세포가 외부로부터 자외선 등과 같은 자극이 가해지면 이를 극복하기 위한 수단으로 멜라 닌을 합성하는 메커니즘과 관련하여 연구가 이루어지고 있다 (Jung 2012). 미백기능성화장품은 멜라노사이트 내에서의 멜라 닌 생성을 억제하는 것, 멜라노사이트 자극물질을 조절하는 것 과 멜라닌 배설을 촉진시키는 것으로 구분된다(Jung 2012). 본 논문은 국화과 꽃이 생산하는 대사물질로부터 미백효능을 가지 는 기능성 화장품 소재를 개발하기 위하여 꽃 추출물 및 분획 물을 제조하고, 이들의 총 페놀, 총 플라보노이드의 양, 1,1diphenyl-2-picrylhydrazyl (DPPH) 라디칼 소거 활성 및 멜라닌 생합성의 초기단계에 관여하는 타이로시나아제의 활성을 억제 하는 정도를 검토하여 미백 기능성 화장품을 개발하는 데 있어 서, 꽃의 활용 가능성을 평가하기 위하여 실시하였다(Jung 2012).

\section{재료 및 방법}

\section{실험 재료}

본 실험에 사용한 국화과 꽃은 18종으로 수집 시기는 2015년 10 월 12 일이며, 충청남도 농업기술원 예산 국화시험장에서 제공 받거나, 서울시 양재꽃시장에서 구입하였다. 꽃은 꽃잎, 암술, 수 술, 씨방 과 꽃받침으로 나누어져 있는데, 이번에 수집한 꽃은 모든 부위를 사용하였다. 건조하지 않은 생체 꽃 시료 $30 \mathrm{~g}$ 을 $100 \% \mathrm{MeOH} 150 \mathrm{~mL}$ 및 $80 \% \mathrm{MeOH} 150 \mathrm{~mL}$ 로 실온에서 추출하였다. 얻어진 추출물은 용매의 극성을 이용하여 $n$-hexane $(100 \mathrm{~mL} \times 2), \quad$ EtOAc $(100 \mathrm{~mL} \times 2), n-\mathrm{BuOH}(100 \mathrm{~mL} \times 2)$ 및 물 $(100 \mathrm{~mL})$ 로 분획물을 제조하였다. 자세한 내용을 Table 1에 나타냈다. 표본시료(KHU-15-515 KHU-15-532)는 경희대학교 천 연물화학 실험실에 보관되어 있다. 본 연구에서 사용된 Folin \& Ciocalteu's phenol 시약, 3,4,5-trihydroxybenzoic acid (gallic acid), naringin, DPPH, kojic acid, mushroom tyrosinase, LDOPA는 Sigma Aldrich Co. (St. Louis, MO, USA)에서, $\mathrm{Na}_{2} \mathrm{CO}_{3}$, diethyleneglycol, $\mathrm{NaOH}$ 는 덕산약품(Ansan, Korea)에 서 구입하여 사용하였다. 그 외의 실험에 사용한 시약은 대정
화금주식회사(Siheung, Korea)에서 1급 시약을 구입하여 사용하 였다. 감압 농축기는 Eyela CCA-1110 (Tokyo, Japan)을 사용 하였으며, UV spectrophotometer는 Shimadzu UV-16-1 (Tokyo, Japan)와 Tecan UV/Vis (Hombrechtikon, Switzerland)를 사용 하였다.

\section{추출물 및 분획물의 총 페놀 함량 측정}

총 페놀 함량은 Folin-Cioaclteu's phenol 시약을 이용한 발색법 (Singleton과 Rossi 1965)을 변형하여 측정하였다. 추출물 및 분 획물을 증류수에 녹여 $200 \mathrm{ppm}$ 의 시료를 제조하고 그 중 200 $\mu \mathrm{L}$ 를 취한 뒤 $100 \mu \mathrm{L}$ 의 $50 \%$ Folin-Cioaclteu's phenol 시약을 첨가하였다. 이들을 실온에서 30 분간 반응시킨 후 $750 \mathrm{~nm}$ 에서 흡광도를 측정하였으며 위 과정을 3 회 반복하였다. 측정한 값 은 gallic acid 표준정량곡선을 이용하여 $1 \mathrm{~g}$ 의 추출물 혹은 분 획물 중에 함유된 gallic acid의 양(mg GAE/g DW)으로 제시 하였다.

\section{추출물 및 분획물의 총 플라보노이드 함량 측정}

총 플라보노이드 함량은 diethylene glycol을 이용한 발색법 (Abeysinghe 등, 2007)을 변형하여 측정하였다. 추출물 및 분획 물을 증류수에 녹여 $200 \mathrm{ppm}$ 의 시료를 제조하고 그 중 200 $\mu \mathrm{L}$ 를 취한 뒤 diethylene glycol $2 \mathrm{~mL}$ 와 혼합하였다. 여기에 $1 \mathrm{~N} \mathrm{NaOH}$ 용액 $200 \mu \mathrm{L}$ 를 첨가하여 $37^{\circ} \mathrm{C}$ (water bath)에서 1 시간 동안 반응시켰다. 이후 $420 \mathrm{~nm}$ 에서 흡광도를 측정하였다. 위 과정을 3 회 반복하였으며 측정한 값은 naringin 표준정량곡 선을 이용하여 $1 \mathrm{~g}$ 의 추출물 혹은 분획물 중에 함유된 naringin 의 양 $(\mathrm{mg} \mathrm{NAE} / \mathrm{g} \mathrm{DW})$ 으로 제시하였다.

\section{추출물 및 분획물의 DPPH radical 소거활성 측정}

Brand-Williams 등의 방법에 의하여 소거활성을 측정하였다. 추 출물 및 각 분획물의 농축 건조물을 $25 \mathrm{ppm}(99.5 \%$ methanol) 의 농도로 조제한 용액 $0.1 \mathrm{~mL}$ (control: $99.5 \%$ methanol)에 $0.1 \mathrm{mM}$ DPPH용액(99.5\% methanol) $1.9 \mathrm{~mL}$ 를 가하였다. Vortex mixer로 10 초간 진탕한 후 $37^{\circ} \mathrm{C}$ 에서 30 분간 반응시켰 다. 이후 UV spectrophotometer를 이용하여 $517 \mathrm{~nm}$ 에서 흡광도 를 측정하였다. 양성 대조 약물로는 $\alpha$-tocopherol을 $12.5,25$, $50,100 \mathrm{ppm}$ (99.5\% methanol) 의 4가지 농도로 용액을 조제 하여 측정하였다. 각 시료의 항산화작용은 $\mathrm{DPPH}$ 에 대한 전자 공여능(Electron donating ability, EDA \%)으로 나타내었다. EDA $(\%)=\{($ Control O.D. - Sample O.D. $) /$ Control O.D. $\} \times$ 100 (\%); Sample O.D.: 시료를 가한 시험액의 흡광도; Control O.D.: 시료 대신 methanol을 가한 시험액의 흡광도. 효과가 좋 은 분획물은 농도를 낮게 하여 3 가지 농도로 같은 방법으로 측 정하였다. 각 실험은 3 반복으로 실시하였다.

\section{추출물 및 분흭물의 tyrosianase 활성 억제 효과 측정}

Tyrosinase 활성 억제효과는 L-DOPA 기질과 tyrosinase의 반응 을 거쳐 생성되는 dopachrome을 UV spectrometer로 측정하여 확인하였다(Mason과 Peterson 1965). 꽃으로부터 얻은 추출물과 분획물 시료 용액에(1,000 ppm), $8.3 \mathrm{mM} \mathrm{L-DOPA} \mathrm{기질,} 2000$ unit mushroom tyrosinase 순으로 첨가해 $37^{\circ} \mathrm{C}$ heating block 에서 30 분 동안 배양한 후, $475 \mathrm{~nm}$ 에서 dopachrome의 생성 정 
Table 1 Flowers collected for this study and the yield of solvent extract and fractions

\begin{tabular}{|c|c|c|c|c|c|c|c|c|c|c|c|}
\hline \multirow[b]{2}{*}{ No } & \multirow[b]{2}{*}{ Scientific Name } & \multirow[b]{2}{*}{ Date } & \multirow[b]{2}{*}{ Place } & \multirow[b]{2}{*}{ Color } & \multirow{2}{*}{$\begin{array}{c}\text { Average } \\
\text { weight } \\
(\mathrm{g})^{\mathrm{c})}\end{array}$} & \multirow{2}{*}{$\begin{array}{l}\text { Diameter - } \\
(\mathrm{cm})^{\mathrm{d})}\end{array}$} & \multicolumn{5}{|c|}{ Yield $(\%)^{\mathrm{e})}$} \\
\hline & & & & & & & $\begin{array}{l}\mathrm{MeOH} \\
\text { ext. }^{f}\end{array}$ & $\begin{array}{l}n \text {-hexane } \\
\text { fr }^{\mathrm{g})}\end{array}$ & EtOAc fr & $\begin{array}{l}n-\mathrm{BuOH} \\
\text { fr. }\end{array}$ & $\mathrm{H}_{2} \mathrm{O}$ fr. \\
\hline 1 & Aster yomena & Oct, 2015 & YJFM $^{\text {a) }}$ & Pink & 0.08 & 2.1 & 6.05 & 0.83 & 0.61 & 1.46 & 3.15 \\
\hline 2 & Aster ageratoides & Oct, 2015 & YJFM $^{\text {a) }}$ & Violet & 0.12 & 2.7 & 6.97 & 1.32 & 1.10 & 1.88 & 2.67 \\
\hline 3 & Aster spathulifolius & Oct, 2015 & YJFM $^{\text {a) }}$ & Violet & 0.41 & 3.4 & 8.46 & 1.65 & 0.72 & 1.25 & 4.84 \\
\hline 4 & Callistephus chinensis & Oct, 2015 & YJFM $^{\text {a) }}$ & Red & 0.34 & 2.0 & 6.96 & 1.68 & 0.31 & 1.48 & 3.49 \\
\hline 5 & Conoclinium coelestinum & Oct, 2015 & YJFM $^{\text {a) }}$ & Violet & 0.10 & 0.4 & 6.63 & 1.29 & 0.77 & 0.95 & 3.62 \\
\hline 6 & Cosmos bipinnatus White & Oct, 2015 & YJFM $^{\text {a) }}$ & White & 0.29 & 5.5 & 6.21 & 0.66 & 2.24 & 1.11 & 2.20 \\
\hline 7 & Cosmos bipinnatus Pink & Oct, 2015 & YJFM $^{\text {a) }}$ & Pink & 0.29 & 5.2 & 9.09 & 0.67 & 0.30 & 4.21 & 3.91 \\
\hline 8 & Cosmos bipinnatus Red & Oct, 2015 & YJFM $^{\text {a) }}$ & Red & 0.33 & 5.0 & 5.54 & 0.59 & 0.34 & 0.92 & 3.69 \\
\hline 9 & $\begin{array}{l}\text { Chrysanthemum morifolium } \\
\text { Ramat. Yesmorning }\end{array}$ & Oct, 2015 & $\mathrm{CYOY}^{\mathrm{b})}$ & Violet & 9.24 & 4.3 & 6.44 & 0.58 & 0.46 & 1.80 & 3.60 \\
\hline 10 & $\begin{array}{c}\text { Chrysanthemum morifolium } \\
\text { Ramat. Froggy }\end{array}$ & Oct, 2015 & YJFM $^{\text {a) }}$ & Green & 9.91 & 3.5 & 1.44 & 0.11 & 0.15 & 0.38 & 0.80 \\
\hline 11 & $\begin{array}{l}\text { Chrysanthemum morifolium } \\
\text { Ramat. Yellow Marble }\end{array}$ & Oct, 2015 & $\mathrm{CYOY}^{\mathrm{b})}$ & Yellow & 9.38 & 4.2 & 3.66 & 0.31 & 1.78 & 0.29 & 1.28 \\
\hline 12 & $\begin{array}{c}\text { Chrysanthemum morifolium } \\
\text { Ramat. Rosa }\end{array}$ & Oct, 2015 & YJFM $^{\text {a) }}$ & Pink & 8.74 & 3.9 & 0.68 & 0.12 & 0.15 & 0.26 & 0.15 \\
\hline 13 & $\begin{array}{l}\text { Chrysanthemum morifolium } \\
\text { Ramat. Geumhwa }\end{array}$ & Oct, 2015 & $\mathrm{CYOY}^{\mathrm{b})}$ & Yellow & 10.00 & 22.4 & 0.19 & 0.04 & 0.01 & 0.02 & 0.12 \\
\hline 14 & $\begin{array}{l}\text { Chrysanthemum morifolium } \\
\text { Ramat. Baekseol }\end{array}$ & Oct, 2015 & $\mathrm{CYOY}^{\mathrm{b})}$ & White & 12.50 & 34.2 & 0.36 & 0.02 & 0.01 & 0.02 & 0.31 \\
\hline 15 & $\begin{array}{c}\text { Chrysanthemum morifolium } \\
\text { Ramat. Hi Maya }\end{array}$ & Oct, 2015 & $\mathrm{CYOY}^{\mathrm{b})}$ & Violet & 27.80 & 12.0 & 0.30 & 0.02 & 0.01 & 0.02 & 0.25 \\
\hline 16 & $\begin{array}{l}\text { Chrysanthemum morifolium } \\
\text { Ramat. Pomponmum }\end{array}$ & Oct, 2015 & YJFM $^{\text {a) }}$ & White & 0.31 & 1.7 & 0.22 & 0.02 & 0.02 & 0.02 & 0.16 \\
\hline 17 & $\begin{array}{l}\text { Chrysanthemum morifolium } \\
\text { Ramat. Popgreen }\end{array}$ & Oct, 2015 & YJFM $^{\text {a) }}$ & Green & 1.99 & 2.7 & 0.39 & 0.19 & 0.01 & 0.09 & 0.10 \\
\hline 18 & $\begin{array}{l}\text { Chrysanthemum morifolium } \\
\text { Ramat. Hongsim }\end{array}$ & Oct, 2015 & YJFM $^{\text {a) }}$ & Red & 2.03 & 2.9 & 0.22 & 0.02 & 0.01 & 0.02 & 0.17 \\
\hline
\end{tabular}

${ }^{\mathrm{a})}$ YJFM: Yangjae Flower Market, Seoul, Korea; ${ }^{\mathrm{b})} \mathrm{CYOY}$ : Yeoktap-ri, Oga-myeon, Yesan-gun, Chungcheongnam-do, Korea; ${ }^{\mathrm{c}}$ Average weight (g): Average weight of random 10 samples; ${ }^{d}$ Diameter $(\mathrm{cm})$ : Average diameter of random 10 samples; ${ }^{\text {e) }}$ Yield $(\%)$ : Weight of extract or fractions $(\mathrm{g}) /$ Weight of fresh flowers $(\mathrm{g}) ;{ }^{\mathrm{f}}$ ext.: extract; ${ }^{\mathrm{g}}$ fr.: fraction

도를 흡광도로 측정하였다. 다음과 같은 식으로 활성 억제 정 도를 $\%$ 로 나타냈다. Tyrosinase 활성 억제 정도 $=\{(\mathrm{A}-\mathrm{B})-\mathrm{C} /$ $(\mathrm{A}-\mathrm{B})\} \times 100(\%) . \mathrm{A}$ 는 시료 대신 buffer를 넣었을 때, $\mathrm{B}$ 는 시 료와 tyrosinase 대신 buffer를 넣었을 때 측정한 흡광도이다. C 는 시료를 넣고 반응 후 측정한 흡광도이다. 각 실험은 3 반복 으로 실시하였다.

\section{결과 및 고찰}

국화꽃 추출물의 화장품 기능성을 검정하기 위하여, 18 종의 꽃 을 수집하였다. 이번 실험에 사용된 국화과 꽃은 쑥부쟁이(Aster yomena), 까실쑥부쟁이(A. ageratoides), 해국(A. spathulifolius), 과꽃(Callistephus chinensis), 서양등골나무(Conoclinium coelestimum), 하얀 코스모스(Cosmos bipinnatus White), 분홍 코스모스(C. bipinnatus Pink), 빨간 코스모스(C. bipinnatus Red), 국화 예스 모닝(Chrysanthemum morifolium Ramat. Yesmorning), 국화 프 로기(C. morifolium Ramat. Froggy), 국화 옐로우 마블 $(C$. morifolium Ramat. Yellow Marble), 국화 로사(C. morifolium
Ramat. Rosa), 국화 금화(C. morifolium Ramat. Geumhwa), 국화 백설(C. morifolium Ramat. Baekseol), 국화 하이마야 $(C$. morifolium Ramat. Hi Maya), 국화 퐁퐁(C. morifolium Ramat. Pomponmum), 국화 팝그린(C. morifolium Ramat. Popgreen), 국화 홍심(C. morifolium Ramat. Hongsim)이었다(Table 1).

이 중 $\mathrm{MeOH}$ 로 생체 꽃 시료를 추출한 추출물의 수율은 국 화 금화가 $0.19 \%$ 로 가장 낮았으며, 분홍 코스모스, 해국, 까실 쑥부쟁이가 각각 $9.17,8.81$ 및 $5.59 \%$ 로 높게 나타났다. 꽃은 수정 매개충을 유인하기 위하여 향기성분을 함유하고 있다. 대 부분의 향기성분은 용매분획 하였을 때, 매우 비극성도가 높은 $n$-hexane 층에 모이게 된다. $n$-Hexane 분획의 수율을 보면 국 화 백설, 국화 하이마야, 국화 홍심이 각각 $0.02 \%$ 로 매우 낮았 으나, 과꽃, 해국, 까실쑥부쟁이는 각각 $1.68,1.65$ 및 $1.32 \%$ 의 순으로 높게 나타났다. EtOAc 분획에는 주로 터페노이드나 플 라보노이드 중에서 상대적으로 극성이 낮은 성분들이 함유된다. 국화 금화, 국화 백설, 국화 하이마야, 국화 퐁퐁, 국화 홍심은 EtOAc 분획의 수율이 모두 $0.01 \%$ 로 매우 낮았지만, 하얀 코 스모스와 까실쑥부쟁이는 각각 2.24 와 $1.10 \%$ 로 비교적 높게 나 타났다. 수율이 높게 나타난 분획에 대하여 TLC 하였을 때, 모 


\section{Total phenolics}

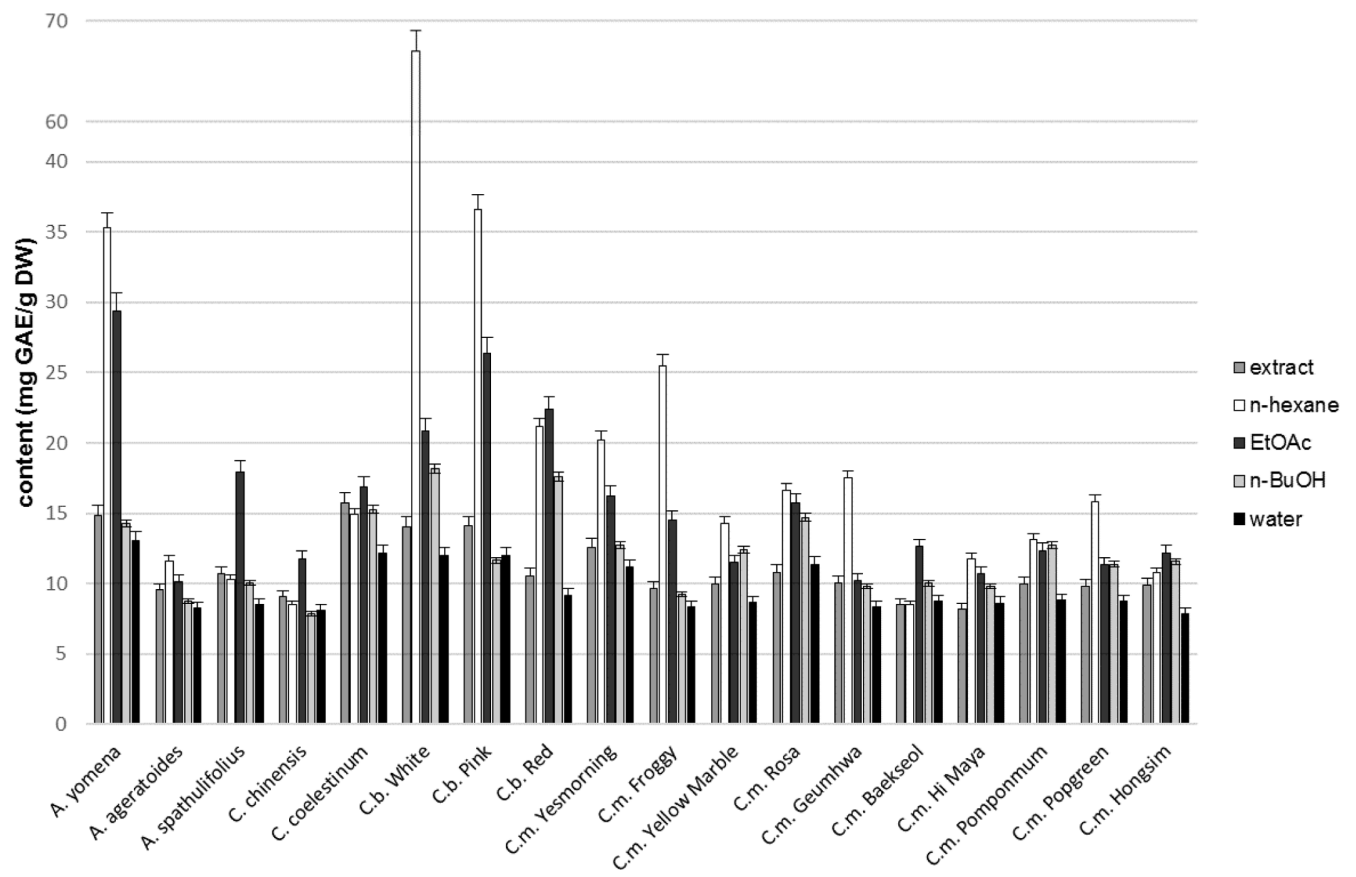

Fig. 1 Total phenolics of the extract and fractions obtained from the flower of Compositae plants

두 터페노이드의 spot이 진하게 나타났다. $n-\mathrm{BuOH}$ 분획에는 터 페노이드와 플라보노이드 중에서 상대적으로 극성이 높은 물질 이나 페놀산, 사포닌과 같은 배당체가 주로 함유되어 있다. 국 화 금화, 국화 백설, 국화 하이마야, 국화 퐁퐁, 국화 홍심의 수 율은 모두 $0.02 \%$ 로 매우 낮게 나타났으며, 높은 것은 분홍 코 스모스, 해국, 국화 예스모닝이 각각 $4.21,1.88,1.80 \%$ 로 나타 났으며, TLC 실험에서도 플라보노이드, 페놀산 등의 뚜렷한 spot을 보였다. 물 분획에는 당이나 유기산, 아미노산 과 같은 일차대사산물이 함유되어 있으며, 색이 진한 꽃의 경우 안토시 아닌 색소도 물층으로 이동하게 된다. 이번 실험에서 사용한 시 료는 꽃이기 때문에 과당, 설탕이 주요 성분으로 존재한다. 수 율이 가장 낮은 것이 국화 팝그린의 $0.10 \%$ 이며, 가장 높은 것 은 까실 쑥부쟁이의 $4.84 \%$ 였으며, 모든 꽃의 분획에서 물 분 획의 수율이 비교적 높게 나타났다. TLC에서도 당과 안토시아 닌의 spot이 뚜렷하게 나타났다.

꽃은 수정 매개충을 유인하기 위하여 향기물질인 정유성분과, 색과 UV 를 나타내는 안토시아닌이나 플라보노이드와 같은 페 놀성화합물을 함유하고 있다(Kim 등, 1999). 그 외에도 항알러 지, 항균성을 가지는 플라보노이드 화합물 및 다양한 이차대사 산물을 함유하고 있다(Eun 등, 1996). 특히 페놀성 화합물은 항 산화활성 (Frankel 등, 1993; Rice-Evans 등, 1995), 항염증활성 (Cicerale 등, 2010) 및 다양한 약리활성과 화장품의 기능성을 나타내는 것으로 보고되어 있다. 따라서 이번에 수집한 꽃의 추 출물 및 분획물에 대하여 총 페놀 및 총 플라보노이드 함량을 측정하였다.

총 페놀함량의 측정은 Folin-Cioaclteu's phenol 시약을 이용 한 발색법(singleton과 Rossi 1965)을 변형하여 이용하였으며, 대 조화합물로는 gallic acid 를 사용하였다. Gallic acid를 위 방법
을 이용하여 농도별로 측정한 결과 $\mathrm{y}=0.5516 \mathrm{x}-3.3448\left(\mathrm{r}^{2}=\right.$ $0.9996)$ 의 검량선을 얻었다. Fig. 1을 보면 알 수 있듯이 EtOAc와 $n-\mathrm{BuOH}$ 분획이 물 분획과 $n$-hexane 분획에 비하여 많은 양의 phenol을 함유함을 알 수 있었으며, 그 중에서도 특 히 쑥부쟁이의 $n$-hexane 및 EtOAc 분획, 하얀 코스모스의 $n$ hexane 분획, 분홍 코스모스의 $n$-hexane 및 EtOAc 분획의 총 페놀 함량이 높음을 알 수 있었다. 각 분획들에 $35.33,29.38$, $67.07,36.58,26.40 \mathrm{mg} \mathrm{GAE} / \mathrm{g} \mathrm{DW}$ 가 함유되어 있는 것으로 나타났다(Fig. 1). 그래프에서 알 수 있듯이 하얀 코스모스의 $n$ hexane 분획에서 가장 높은 함량을 나타내었다.

총 플라보노이드양의 측정은 diethylene glycol을 이용한 발색 법(Abeysinghe 등, 2007)을 변형하여 실험하였으며, 대조화합물 로는 naringin을 사용하였다. Naringin을 위 방법을 이용하여 농 도별로 측정한 결과 $\mathrm{y}=1323.8 \mathrm{x}-397.3\left(\mathrm{r}^{2}=0.9947\right)$ 의 검량선을 얻었다. Fig. 2 를 보면 알 수 있듯이 EtOAc와 $n-\mathrm{BuOH}$ 분획이 물 분획과 $n$-hexane 분획에 비하여 많은 양의 플라보노이드를 함유함을 알 수 있었다. 그 중에서도 쑥부쟁이의 EtOAc 분획, 하얀 코스모스의 EtOAc 분획, 빨간 코스모스의 EtOAc 분획, 국화 프로기의 EtOAc 분획 그리고 국화 하이마야의 EtOAc 분 획의 총 플라보노이드 함량이 높음을 알 수 있었다. 각 분획들 에 $133.48,54.38,54.28,70.75,34.29 \mathrm{mg} \mathrm{NAE} / \mathrm{g} \mathrm{DW}$ 가 함 유되어 있는 것으로 나타났다(Fig. 2). 쑥부쟁이의 EtOAc 분획 에서 플라보노이드 함량이 다른 식물의 분획에 비해 월등히 높 게 나타났다.

생체세포는 살아가는 과정에서 호흡을 통해 세포내 에너지를 생성하는데 필요한 산소를 공급한다. 이 과정에서 흡입한 산소 중 일부가 자연적으로 활성산소로 전환되게 되는데, 이 활성산 소는 불안정하여 주변의 세포들에게 산화적 스트레스를 유발시 
Total flavonoids

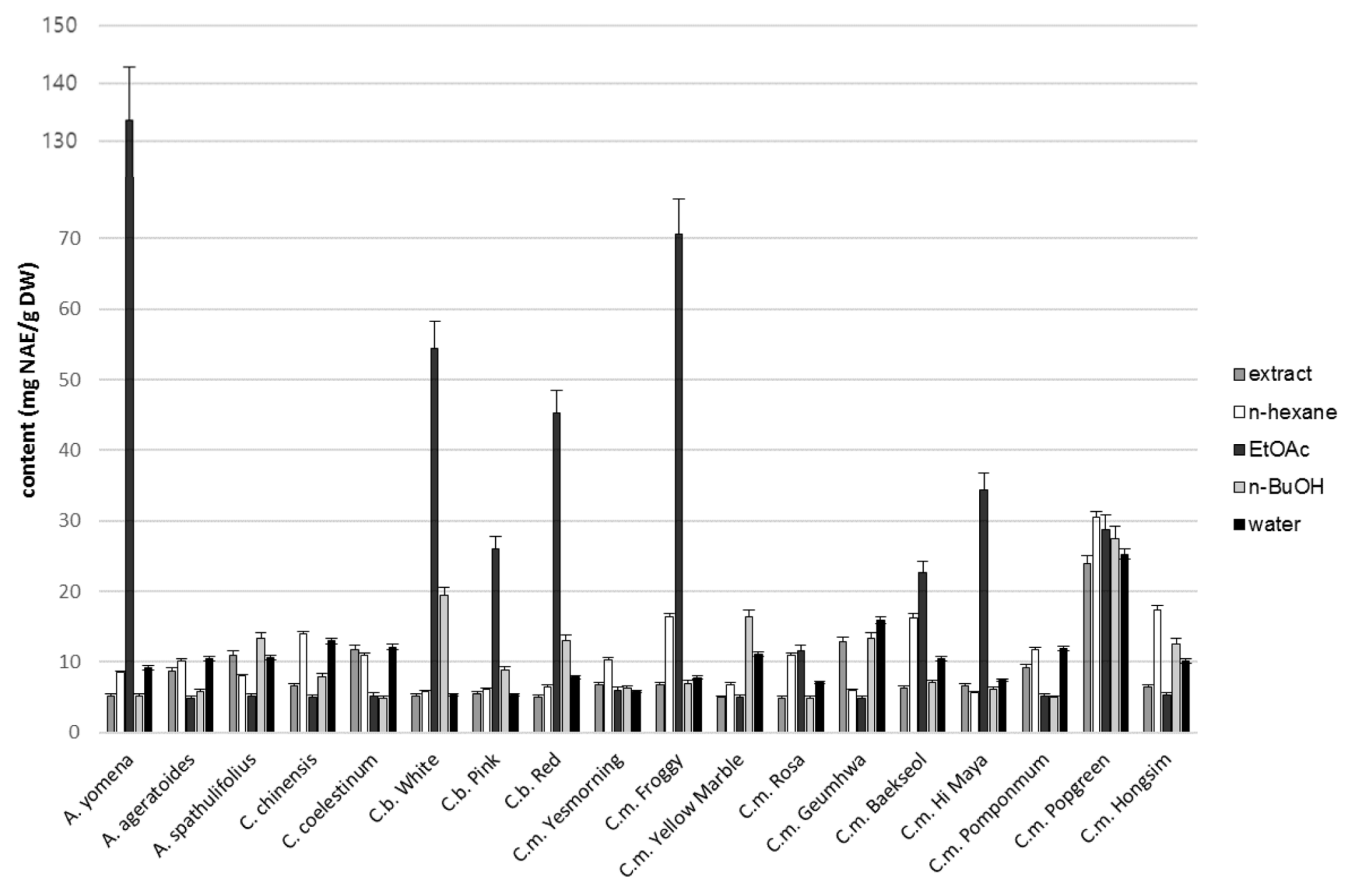

Fig. 2 Total flavonoids of the extract and fractions obtained from the flower of Compositae plants

킨다. 각종 산화성 물질들의 생체 내 작용은 생체막지질의 과 산화, DNA 변성, 단백성분의 손상, 효소불활성화 등 다양한 세 포 손상과 연관되어 있다. 또한 산화적 스트레스가 세포의 항 산화계 활성의 수용력을 초과할 시에 세포 재관류 손상, 동맥 경화, 발암, 노화촉진 등의 다양한 병변을 초래한다(Sies 1997). 본 실험에 사용 된 DPPH (Diphenylpicryl hydrazyl)의 질소원 자가 불안정한 상태(Radical) 에 있으므로 쉽게 수소원자를 받 아들이는 성질을 가지고 있어 항산화성 물질과 반응하여 수소 원자를 받아들임으로써 자체의 정색성을 잃는 점을 이용하였다 (Sharma와 Bhat 2009). 라디컬 소거활성의 측정은 BrandWilliams 법(Brand-Williams 등, 1995) 등을 사용하였으며, 대조 화합물로는 $\alpha$-tocopherol을 사용하였다. $\alpha$-Tocopherol 을 위 방 법을 이용하여 농도별로 측정한 결과 $\mathrm{y}=0.1089 \mathrm{x}+6.1446\left(\mathrm{r}^{2}=\right.$ $0.9966)$ 의 검량선을 얻었다. 추출물과 $n$-hexane, EtOAc, $n$ $\mathrm{BuOH}$, 물 층의 분획물에 대해서 실험을 진행하였고 그 결과는 그래프로 나타내었다(Fig. 3). 양성 대조군인 $\alpha$-tocopherol은 농 도를 각각 $12.5,25,100,200,400,800 \mathrm{ppm}$ 으로 설정하여 각 각의 라디칼 소거활성을 통해 $400 \mathrm{ppm}$ 의 농도에서 약 $50 \%$ 의 $\mathrm{EDA}$ 값을 나타내었으므로 각 추출물과 분획물의 농도를 400 $\mathrm{ppm}$ 으로 설정하여 실험하였다. 실험 결과 쑥부쟁이의 $\mathrm{EtOAc}$ 분획이 $88.5 \%$, 하얀 코스모스의 EtOAc 분획이 $60.0 \%$, 분홍 코스모스의 $\mathrm{EtOAc}$ 분획이 $60.1 \%$, 국화 옐로우마블의 $\mathrm{EtOAc}$ 분획이 $78.3 \%$, 국화 로사의 $\mathrm{MeOH}$ 추출물이 $58.5 \%$ 의 높은 라디칼 소거 활성을 나타내었다. 위의 자료들을 모두 종합해 볼 때, 쑥부쟁이의 EtOAc 분획과 국화 옐로우마블의 EtOAc 분획 에서 특히 높은 라디칼 소거 활성이 나타나는 것으로 확인되 었다.

생체 내에서 멜라닌세포는 자외선으로부터 피부를 보호하기
위해 멜라닌을 생성한다. 멜라닌은 크게 흑색인 eumelanin과 갈 색인 pheomelanin 그리고 고등식물이나 균에서 생성하는 allomelanin으로 나눌 수 있는데 이중 eumelanin과 pheomelanin 생성으로 피부색이 결정된다(Kazumasa와 Shoauke 2002). 멜라 닌은 tyrosine 이 tyrosinase라는 효소를 통해 3,4-dihyroxyphenylalanine (DOPA)을 생성하며, 이어서 hydroxylation 반응 이 진행되면서 dopaquinone, dopachrome을 거쳐 멜라닌으로 생 합성된다. 이때 tyrosinase의 효소반응이 멜라닌 생합성 반응의 반응속도결정 단계로 멜라닌 합성을 저해하기 위해서는 이 반 응을 억제해야 한다(Shosuke 2003). 이와 같은 이유로 많은 선 행 연구에서 tyrosinase의 작용에 대한 억제제를 탐색하는 in vitro 상의 연구를 결과가 보고되었으며, 기능성 화장품의 개발 에서 멜라닌 합성을 억제하여 나타내는 미백효과를 평가를 하 기 위해 tyrosinase inhibition 정도를 측정한다. Tyrosinase 는 tyrosine으로부터 물 한분자를 제거하고 quinone의 구조를 만드 는 반응의 촉매역할을 하며 tyrosinase inhibition assay에서는 주로 mushroom tyrosinase (EC 1.14.18.1)를 사용한다(Behbahani 등, 1993). 18종의 꽃으로부터 얻은 추출물 및 분획물의 미백활 성을 탐색하기 위해 tyrosinase 활성 억제 실험을 진행하였다. Tyrosinase 활성 억제 정도는 퍼센트로 계산되어 $1,000 \mathrm{ppm}$ 농 도의 kojic acid를 대조군으로 비교하여 값이 클수록 억제 효과 가 높은 것을 의미한다. 추출물과 $n$-hexane, EtOAc, $n-\mathrm{BuOH}$, 물 층의 분획물에 대해서 실험을 진행하였고 그 결과는 Fig. 4 와 같다. 양성대조군인 kojic acid의 tyrosinase 활성 억제 정도 는 $78.8 \%$ 를 나타내었다. 실험 결과 서양등골나무의 EtOAc 분 획이 $31.5 \%$, 하얀 코스모스의 $\mathrm{EtOAc}$ 분획이 $35.2 \%$, 빨간 코 스모스의 EtOAc 분획이 $36.7 \%$, 국화 하이마야의 EtOAc 분획 이 $39.8 \%$, 국화 홍심의 $\mathrm{EtOAc}$ 분획이 $44.7 \%$ 의 억제효과를 
DPPH Radical Scanenge assay

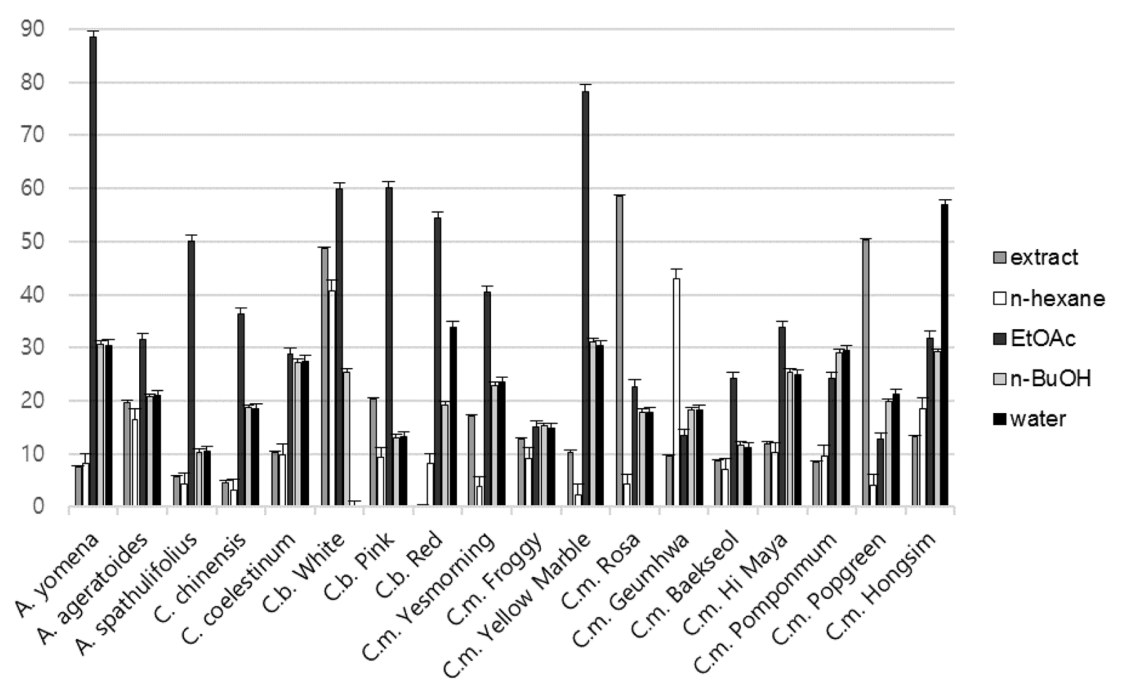

Fig. 3 DPPH radical scavenging effect of the extract and fractions obtained from the flower of Compositae plants

Tyrosinase Inhibition assay

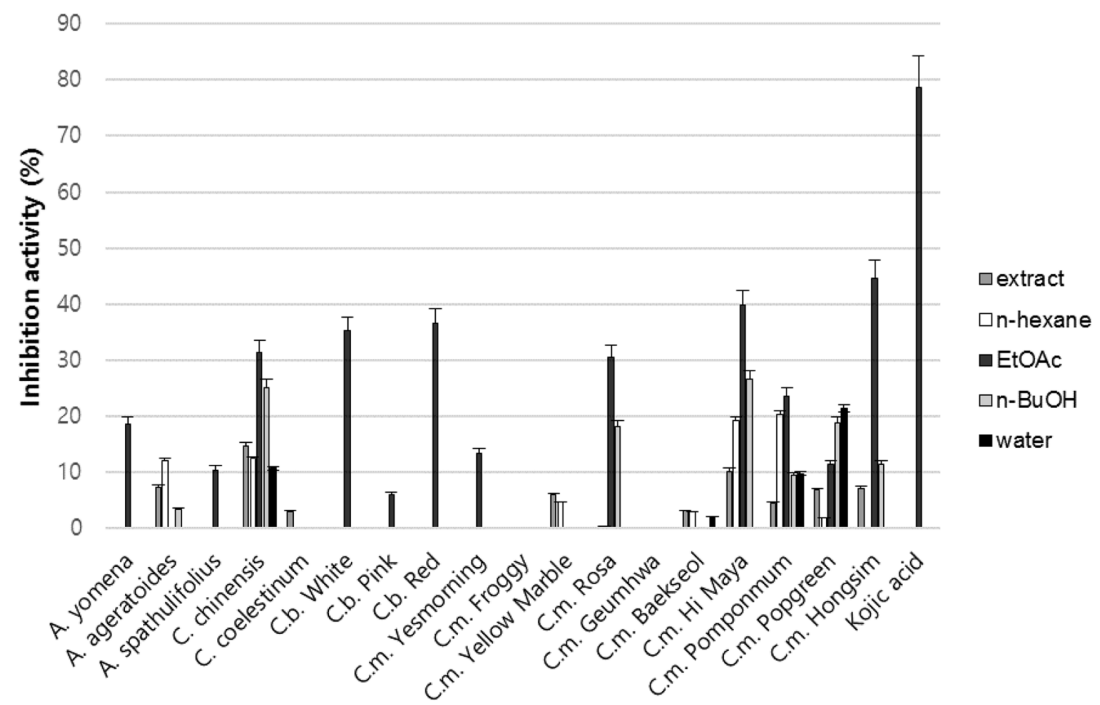

Fig. 4 Inhibitory effect obtained of the extract and fractions from the flower of Compositae plants on tyrosinase activity

보여 우수한 tyrosinase 활성 억제 효과를 가지는 것으로 나타 났다.

쑥부쟁이의 $n$-hexane 및 EtOAc 분획물은 총 페놀양이 높게 나타났으며, 그 중 $\mathrm{EtOAc}$ 의 분획은 총 플라보노이드의 양 역 시 높게 나왔고, DPPH radical scavenge 효과도 높게 나타났다. 하얀 코스모스의 $n$-hexane 분획물은 총 페놀양이 높게 나타났 고, EtOAc 분획의 총 플라보노이드의 양이 높게 나타났으며 이 분획은 DPPH radical scavenge 효과도 높고 tyrosinase 활성도 효과적으로 억제하였다. 분홍 코스모스의 $n$-hexane 및 EtOAc 분획물은 총 페놀 양이 높게 나타났으며, 그 중 $\mathrm{EtOAc}$ 의 분획 은 DPPH radical 소거활성이 높게 나타났다. 빨간 코스모스와 국화 하이마야의 경우는 모두 EtOAc 분획에서 총 플라보노이
드 양이 높게 나타났으며 tyrosinase 활성도 효과적으로 억제하 였다. 높은 활성을 보이는 꽃들에 대해 문헌검색을 해본 결과 아직까지 총 페놀, 총 플라보노이드, DPPH radical 소거활성, tyrosinase 저해 활성에 관한 연구가 진행 된 적이 없었다. 특히 쑥부쟁이 꽃과 국화 하이마야에 관해서는 전혀 연구 된 바가 없다. 코스모스는 항산화 효능을 가진다고 보고되었으며(Jang 등, 2008), 코스모스를 비롯한 국화과(Compositae) 식물들이 항 염증 효능을 가진다고 보고되었다(Akihisa 등, 1996). 따라서 쑥 부쟁이, 하얀 코스모스, 분홍 코스모스, 빨간 코스모스 및 국화 하이마야에 대해서는 미백물질개발에 관한 심도 있는 연구가 필 요한 것으로 사료된다. 


\section{초 록}

18 종의 국화과 식물의 꽃을 $\mathrm{MeOH}$ 로 추출하였다. 농축한 추출 물은 용매의 극성을 이용하여 $n$-hexane, EtOAc, $n$-BuOH 및 물 분획으로 제조하였다. 각 추출물과 분획물에 대하여 총 페 놀 양, 총 플라보노이드 양, DPPH radical scavenge 효과 및 tyrosinase 활성 억제 효과를 측정하였다. 쑥부쟁이(Aster yomena) 의 $n$-hexane 및 EtOAc 분획, 하얀 코스모스(Cosmos bipinnatus White)의 $n$-hexane 분획, 분홍 코스모스(C. bipinnatus Pink)의 $n$-hexane 및 EtOAc 분획에서 총 페놀양이 높게 나타났으며, 쑥 부쟁이(A. yomena)의 $\mathrm{EtOAc}$ 의 분획, 하얀 코스모스 $(C$. bipinnatus White)의 EtOAc 분획, 빨간 코스모스 $(C$. bipinnatus Red)의 EtOAc 분획, 프로기(C. morifolium Froggy)의 EtOAc 분획, 그리고 하이마야(C. morifolium Himaya)의 EtOAc 분획에 서 총 플라보노이드 양이 높게 나타났다. 쑥부쟁이(A. yomena) 의 EtOAc 분획, 하얀 코스모스(C. bipinnatus White)의 EtOAc 분획, 분홍 코스모스(C. bipinnatus Pink)의 EtOAc 분획, 옐로 우마블(C. morifolium Yellowmable)의 EtOAc 분획, 그리고 로 사(C. morifolium Rosa)의 $\mathrm{MeOH}$ 추출물이 $\mathrm{DPPH}$ radical을 효과적으로 포획하였다. 서양들골나무 $(C$. chinensis $)$ 의 EtOAc 분 획, 하얀 코스모스 $(C$. bipinnatus White)의 EtOAc 분획, 빨간 코스모스 $(C$. bipinnatus $\mathrm{Red})$ 의 EtOAc 분획, 하이마야 $(C$. morifolium Himaya)의 EtOAc 분획 그리고 홍심(C. morifolium Hongsim)의 EtOAc 분획이 tyrosinase 활성을 억제하였다. 수율 및 위의 실험 결과를 종합하였을 때 쑥부쟁이(A. yomena), 하 얀 코스모스(C. bipinnatus White), 분홍 코스모스(C. bipinnatus Pink), 빨간 코스모스(C. bipinnatus Red) 및 하이마야 $(C$. morifolium Himaya) 의 다섯 품종이 미백물질개발을 위한 좋은 자원으로 판단되었다.

Keywords 국화·꽃 - 미백 · 총 플라보노이드·총 페놀· 1,1diphenyl-2-picrylhydrazyl $\cdot$ Tyrosinase

감사의 글 본 논문은 농촌진흥청 연구사업(세부과제번호: PJ01141501)의 지원에 의해 이루어진 것입니다. 지원에 감사드립니다.

\section{References}

Abeysinghe DC, Li X, Sun C, Zhang W, Zhou C, Chen K (2007) Bioactive compounds and antioxidant capacities in different edible tissues of citrus fruit of four species. Food Chem 104: 1338-1344

Akihisa T, Yasukawa K, Oinuma H, Kasahara Y, Yamanouchi S, Takido M, Kumaki K, Tamura T (1996) Triterpene alcohols from the flowers of compositae and their anti-inflammatory effects. Phytochem 43: 12551260

Behbahani I, Miller SA, Okeeffe DH (1993) A comparison of mushroom tyrosinase dopaquinone and dopachrome assays using diode-array spectrophotometry: Dopachrome formation vs ascorbate-linked dopaquinone reduction. Microchem J 47: 251-260

Brand-Williams W, Cuvelier ME, Berset C (1995) Use of a free radical method to evaluate antioxidant activity. LWT-Food Sci Technol 28: 2530

Cicerale S, Lisa L, Russell K (2010) Biological activities of phenolic compounds present in virgin olive oil. Int J Mol Sci 11: 458-479

Eun JB, Jung YM, Woo GJ (1996) Identification and determination of dietary fibers and flavonoids in pulp and peel of Korean tangerine. Korean $\mathrm{J}$ Food Sci Technol 28: 371-377

Frankel EN, Kanner J, German JB, Parks E, Kinsella JE (1993) Inhibition of oxidation of human low density lipoproteins by phenolic substances in red wine. Lancet 43: 454-457

Harper JL (1977) The Population Biology of Plants. Academic Press, London Hopkins WG (2006) Introduction to Plant Physiology. John Wiley \& Sons Inc., New York

Im H (2004) The developmental trend and future prospect of the function cosmetics market. Dissertation, Chung-Ang University

Jang IC, Park JH, Park E, Park HR, Lee SC (2008) Antioxidative and antigenotoxic activity of extracts from cosmos (Cosmos bipinnatus) flowers. Plant foods hum nutr 63: 205-210

Jung YJ (2012) Kinetic analysis in tyrosinase inhibition activity of whitening agents. Dissertation, Soongsil University

Kazumasa W, Shoauke I (2002) Advanced chemical methods in melanin determination. Pigment Cell Res 15: 174-183

Kim IW, Shin DH, Choi U (1999) Isolation of antioxidative components from the bark of Rhus verniciflua stokes screened from some Chinese medical plants. Kor J Food Sci Technol 31: 885-863

Kim KH (2005) Effects of horticultural therapy program on physiological and psychological responses of the hospice patients. Dissertation, Keimyung University

Lee SM (2014) Consumer's recognition and actual usage of cosmetic ingredients and functional cosmetics. Dissertation, Seo Kyeong University

Mason HS, Peterson EW (1965) Melanoproteins I. Reactions between enzyme-generated quinones and amino acids. BBA-Gen Subjects 111: 134-146

Rice-Evans CA, Miller NJ, Bolwell PG, Bramley PM, Pridham JB (1995) The relative antioxidant activities of plant-derived polyphenolic flavonoids. Free Radic Res 22: 375-383

Sharma OP, Bhat TK (2009) DPPH antioxidant assay revisited. Food Chem 113: $1202-1205$

Shosuke I (2003) A chemist's view of melanogenesis. Pigments Cell Res 16: 230-236

Sies H (1997) Oxidative stress: Oxidants and antioxidants. Exp Physiol 82: 291-295

Singleton V, Rossi JA (1965) Colorimetry of total phenolics with phosphomolybdic-phosphotungstic acid reagents. Am J Enol Vitic 34: 593-598 